\title{
Digital Rectal Examination for Prostate Cancer Screening in Primary Care: A Systematic Review and Meta-Analysis
}

Leen Naji, MD ${ }^{1}$

Harkanwal Randhawa, BHSc ${ }^{2}$

Zabra Sobani, MSc, $P b D^{3}$

Brittany Dennis, BA, $\mathrm{PbD}^{4}$

Deanna Lautenbach, $P A^{5}$

Owen Kavanagh, BHSc, MD

Monica Bawor, BSc, $P b D^{4}$

Laura Banfield, MLIS ${ }^{6}$

Jason Profetto, MD, CCFP

'Department of Family Medicine, McMaster University, Hamilton, Canada

${ }^{2}$ Michael G. DeGroote School of Medicine, McMaster University, Hamilton, Canada

${ }^{3}$ Faculty of Medicine, University of

Toronto, Toronto, Canada

${ }^{4}$ St George's University of London, London, United Kingdom

${ }^{5}$ Profetto-Savatteri Family Medicine, McMaster University, Hamilton, Canada

${ }^{6}$ Health Sciences Library, McMaster

University, Hamilton, Canada

Conflicts of interest: authors report none.

\section{CORRESPONDING AUTHOR}

Jason Profetto, MD, CCFP

Undergraduate Medical Program

McMaster University

1280 Main St W

Michael DeGroote Centre for Learning and

Discovery (MDCL) -3104

Hamilton, ON L8S 4K1 Canada

Jason@profetto.ca

\begin{abstract}
PURPOSE Although the digital rectal examination (DRE) is commonly performed to screen for prostate cancer, there is limited data to support its use in primary care. This review and meta-analysis aims to evaluate the diagnostic accuracy of DRE in screening for prostate cancer in primary care settings.
\end{abstract}

METHODS We searched MEDLINE, Embase, DARE (Database of Abstracts of Reviews of Effects), Cochrane Central Register of Controlled Trials, Cochrane Database of Systematic Reviews, and CINAHL (Cumulative Index to Nursing and Allied Health Literature) from their inception to June 2016. Six reviewers, in pairs, independently screened citations for eligibility and extracted data. Pooled estimates were calculated for sensitivity, specificity, positive predictive value (PPV), and negative predictive value (NPV) of DRE in primary care settings using an inversevariance meta-analysis. We used QUADAS-2 (Quality Assessment of Diagnostic Accuracy Studies 2) and GRADE (Grades of Recommendation Assessment, Development, and Evaluation) guidelines to assess study risk of bias and quality.

RESULTS Our search yielded 8,217 studies, of which 7 studies with 9,241 patients were included after the screening process. All patients analyzed underwent both DRE and biopsy. Pooled sensitivity of DRE performed by primary care clinicians was $0.51\left(95 \% \mathrm{Cl}, 0.36-0.67 ; \mathrm{I}^{2}=98.4 \%\right)$ and pooled specificity was $0.59(95 \%$ $\left.\mathrm{Cl}, 0.41-0.76 ; \mathrm{I}^{2}=99.4 \%\right)$. Pooled PPV was $0.41\left(95 \% \mathrm{Cl}, 0.31-0.52 ; \mathrm{l}^{2}=97.2 \%\right)$, and pooled NPV was $0.64\left(95 \% \mathrm{Cl}, 0.58-0.70 ; \mathrm{I}^{2}=95.0 \%\right)$. The quality of evidence as assessed with GRADE was very low.

CONCLUSION Given the considerable lack of evidence supporting its efficacy, we recommend against routine performance of DRE to screen for prostate cancer in the primary care setting.

Ann Fam Med 2018;16:149-154. https://doi.org/10.1370/afm.2205

\section{INTRODUCTION}

A pproximately 1.1 million men receive the diagnosis of prostate cancer yearly, making it the most commonly diagnosed malignancy in men after nonmelanoma skin cancers. ${ }^{1}$ As prostate cancer contributes to substantial morbidity and mortality, screening via the digital rectal examination (DRE), prostate-specific antigen (PSA) test, or both has become the mainstay of clinical practice. Almost one-half of Canadian men aged older than 40 years receive a PSA test during their lifetime, and the DRE is frequently incorporated as part of a routine primary care examination in men. ${ }^{2,3}$ Some evidence suggests, however, that the DRE may not significantly reduce mortality, but instead may result in a high number of false-positives leading to unnecessary invasive diagnostic tests that can precipitate pain, erectile dysfunction, and urinary incontinence, as well as overdiagnosis and overtreatment of prostate cancer., ${ }^{2,4-6}$

Recommendations regarding prostate cancer screening have been inconsistent. The Canadian Urological Association recommends screening with both DRE and PSA in all average-risk men aged 50 years and older with a minimum life expectancy of 10 years. ${ }^{7}$ In contrast, the Canadian Task Force on Preventive Health Care recommends against use of the PSA test for 
prostate cancer screening in men aged 55 years or older without a previous diagnosis of prostate cancer. ${ }^{8}$ The lack of consensus stems from a paucity of evidence to either support or refute the clinical utility of DRE, which has overall estimated sensitivity, specificity, and positive predictive value (PPV) of $53.2 \%, 83.6 \%$, and $17.8 \%$, respectively, in asymptomatic men aged 39 to 92 years. ${ }^{9}$

The purpose of this systematic review and metaanalysis was to investigate the diagnostic accuracy of DRE when performed specifically in the primary care setting for prostate cancer screening. To the best of our knowledge, this study is the first to evaluate the diagnostic utility of DRE in primary care. ${ }^{9,10}$ Although Hoogendam et al ${ }^{10}$ aimed to conduct a similar study, careful evaluation of their findings reveals that DREs were not performed by primary care clinicians in all included studies.

\section{METHODS}

\section{Data Sources and Searches}

An experienced health sciences research librarian (L.B.) developed and conducted the search strategy. A combination of key words and subject headings was used to encompass 3 concepts: prostate cancer, digital rectal examination, and biopsy. The following databases were searched from inception to June 18, 2016: MEDLINE, Embase, DARE (Database of Abstracts of Reviews of Effects), Cochrane Central Register of Controlled Trials, Cochrane Database of Systematic Reviews, and CINAHL (Cumulative Index to Nursing and Allied Health Literature) (see Supplemental Appendix available at http://www.annfammed.org/ content/16/2/149/suppl/DC1/). All databases, with the exception of CINAHL, were searched through Ovid. No geographic or date restrictions were applied. NonEnglish studies were excluded.

\section{Study Eligibility Criteria and Selection}

We included all diagnostic studies and systematic reviews investigating the effectiveness of DRE in screening for prostate cancer in a primary care setting. Only studies in which it was evident that a primary care clinician performed the DRE were included. All patients must have received a DRE regardless of their symptoms, PSA level, or other prognostic factors. All included studies must have used biopsy as a means of determining diagnosis. No restrictions were placed on patient sociodemographics.

We accepted the definition of an abnormal DRE used in each study, recognizing that it is defined variably in the literature. All studies must have reported true-positive, true-negative, false-positive, and falsenegative rates of DRE, or provided at least 2 of these values to allow for the calculation of at least 1 of 4 measures: sensitivity, specificity, PPV, or negative predictive value (NPV).

All titles, abstracts, and full-text articles were evaluated independently by 3 pairs of reviewers to determine whether they met the eligibility criteria using Covidence online software. ${ }^{11}$ Any discrepancies that arose were discussed and resolved by consensus, or resolved by a third reviewer when necessary.

\section{Data Extraction}

Two reviewers independently extracted data by using pilot-tested data extraction forms. Any discrepancies in data collection were reconciled as stated above. We obtained information on study characteristics, sample population, and outcome measures (true-positive, truenegative, false-positive, and false-negative rates).

\section{Risk of Bias and Quality Assessment}

Two independent reviewers used the validated Quality Assessment of Diagnostic Accuracy Studies 2 (QUADAS-2) tool to assess the quality of included studies. ${ }^{12}$ Two reviewers independently used the Grading of Recommendations, Assessment, Development, and Evaluation (GRADE) framework for assessing the quality of evidence of our pooled analyses across 5 domains: risk of bias, indirectness, inconsistency, imprecision, and publication bias. ${ }^{13}$

\section{Pooled Analysis}

We performed meta-analysis of the sensitivity, specificity, PPV, and NPV values obtained from the individual studies using a random-effects model weighted by inverse variance. A 2 -sided $\alpha$ level of .05 was considered significant. Heterogeneity was estimated using the $I^{2}$ statistic, which indicates the proportion of total variation in estimates attributed to heterogeneity, as well as the Q statistic. We used a cut-off of $25 \%$ for $I^{2}$ to represent minimal heterogeneity, $50 \%$ to represent moderate heterogeneity, and $75 \%$ to represent high heterogeneity. MedCalc software (version 16.8.4; MedCalc Software BVBA) was used to conduct the meta-analysis. ${ }^{14}$ All other statistical analyses were conducted in R (version 3.0.2; R Project for Statistical Computing).${ }^{15}$ Pooled effects are presented in a forest plot with associated $95 \%$ confidence intervals.

\section{RESULTS}

\section{Study Selection and Characteristics}

We included in this review and meta-analysis 7 studies with 9,241 patients who underwent both DRE and prostate biopsy (Figure 1). ${ }^{16-22}$ The characteristics of these studies are summarized in Table 1. 


\section{Quality and Risk of Bias Assessment}

All 7 studies were considered to have possible risk of bias according to the QUADAS-2 criteria (Table 2 and Supplemental Appendix Figure A1 available at http:// www.annfammed.org/content/16/2/149/suppl/DC1/). Lack of clarity surrounding participant enrollment methods in the majority of studies made it difficult to judge conferred risk of bias or applicability concerns in the patient selection domain. Similarly, risk of bias and applicability for the index test domain were difficult to determine because not all studies explicitly stated their criteria for an abnormal DRE. All 7 studies were deemed to have high risk of bias in the flow and timing domain, as only patients with an abnormal PSA or DRE underwent the reference standard test (ie, prostate biopsy).

\section{Figure 1. PRISMA flowchart for the selection of articles.}

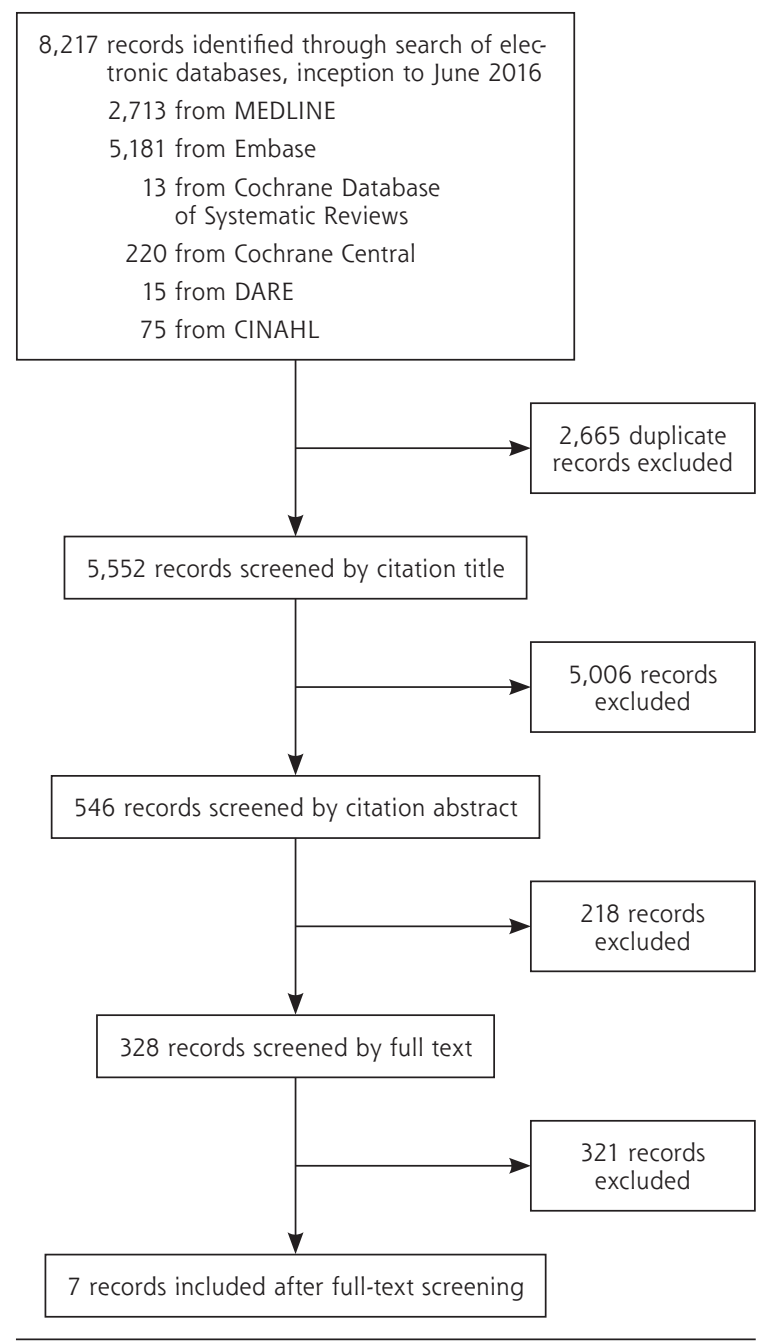

$\mathrm{CINAHL}=$ Cumulative Index to Nursing and Allied Health Literature; DARE $=$ Database of Abstracts of Reviews of Effects; PRISMA = Preferred Reporting Items for Systematic Reviews and Meta-Analyses.
In addition, the studies' overall quality of evidence was considered very low according to the GRADE assessment, downgrading was due mainly to risk of bias, inconsistency, and imprecision (Table 3). ${ }^{13}$ Furthermore, although not all funnel plots were symmetric, they were of limited value in judging publication bias because of the small sample size and heterogeneity. To ensure limited bias from positive studies, we performed manual searches of the reference lists of relevant systematic reviews, and a health sciences librarian (L.B.) accessed papers that were difficult to access or not published online. ${ }^{13}$

\section{Pooled Results}

In pooled analysis of the 7 studies, DRE performed by primary care clinicians generally had poor performance for prostate cancer screening, and there was high heterogeneity across studies. Pooled sensitivity of the DRE performed by primary care clinicians was $0.51(95 \% \mathrm{CI}$, $\left.0.36-0.67 ; \mathrm{I}^{2}=98.4 \%\right)$ and pooled specificity was 0.59 (95\% CI, 0.41-0.76; $\mathrm{I}^{2}=99.4 \%$ ) (Table 4 and Supplemental Appendix Figure A2 available at http://www. annfammed.org/content/16/2/149/suppl/DC1/). Pooled PPV was $0.41\left(95 \% \mathrm{CI}, 0.31-0.52 ; \mathrm{I}^{2}=97.2 \%\right)$, and pooled NPV was $0.64\left(95 \% \mathrm{CI}, 0.58-0.70_{i} \mathrm{I}^{2}=95.0 \%\right)$.

\section{DISCUSSION}

To our knowledge, this is the first systematic review to investigate the effectiveness of DRE for prostate cancer screening in primary care. We found studies of DRE to have flaws resulting in "very low" quality and high levels of between-study heterogeneity. The between-study heterogeneity in our meta-analyses may have resulted from the various definitions used for abnormal DRE or from differences in training for primary care practitioners in performing DRE. ${ }^{16,18-23} \mathrm{~A}$ survey across Canadian medical schools revealed considerable differences in teaching methods and found that approximately one-half of graduating students had never performed a DRE during their clerkship training. ${ }^{24,25}$ Furthermore, only one-half of surveyed primary care physicians reported feeling confident in their ability to detect prostate nodules using DRE. ${ }^{23}$ Inter-examiner reliability between urologists in identifying a prostate finding as suspicious for cancer has been found to be only "fair" after adjusting for chance agreement ( $\kappa=0.22, P=.009),{ }^{26}$ and performance is anticipated to be poorer among non-urologists. We were, however, unable to explore training as a source of heterogeneity through subgroup analyses because the individual studies did not report this factor.

The World Health Organization has stipulated that screening tests should have scientific evidence to dem- 
Table 1. General Characteristics of the Included Studies

\begin{tabular}{|c|c|c|c|c|c|c|}
\hline Study, Year & Country & Design & $\begin{array}{l}\text { Patients } \\
\text { Screened, } \\
\text { No. }\end{array}$ & $\begin{array}{l}\text { Patients } \\
\text { Undergoing } \\
\text { Biopsy, No. }\end{array}$ & $\begin{array}{c}\text { Age } \\
\text { Range, } \\
y\end{array}$ & Indication(s) for Biopsy \\
\hline $\begin{array}{l}\text { Al-Azab et al, }{ }^{16} \\
2007\end{array}$ & Canada & Retrospective chart review & 1,796 & 1,796 & $40-93$ & $\begin{array}{l}\text { Elevated age-specific PSA level or } \\
\text { abnormal DRE findings }\end{array}$ \\
\hline Brett, $^{17} 1998$ & Australia & Prospective cohort study & 211 & 11 & $50-79$ & $\begin{array}{l}\text { Abnormal DRE findings or PSA } \\
\text { level } \geq 4.1 \mathrm{ng} / \mathrm{mL}\end{array}$ \\
\hline $\begin{array}{l}\text { Crawford et al, }{ }_{1}^{18} \\
1999\end{array}$ & $\begin{array}{l}\text { United } \\
\text { States }\end{array}$ & Retrospective chart review & 142,111 & 4,160 & $40-79$ & $\begin{array}{l}\text { Abnormal DRE findings or PSA } \\
\text { level } \geq 4 \mathrm{ng} / \mathrm{mL}\end{array}$ \\
\hline $\begin{array}{l}\text { Elliott et al, }{ }^{19} \\
2008\end{array}$ & $\begin{array}{l}\text { United } \\
\text { States }\end{array}$ & $\begin{array}{l}\text { Retrospective review of } \\
\text { prospectively collected } \\
\text { data }\end{array}$ & 1,564 & 1,564 & N/A & $\begin{array}{l}\text { Abnormal DRE findings and/or } \\
\text { PSA level } \geq 4 \mathrm{ng} / \mathrm{mL}\end{array}$ \\
\hline $\begin{array}{l}\text { Faria et al, }{ }^{20} \\
2012\end{array}$ & Brazil & Prospective cohort study & 17,571 & 1,647 & $45-98$ & $\begin{array}{l}\text { Abnormal DRE findings and/or PSA } \\
\text { level } \geq 4 \mathrm{ng} / \mathrm{mL} \text {; and starting } \\
\text { Nov } 2004, \text { PSA } 2.5-3.9 \mathrm{ng} / \mathrm{mL} \\
\text { and } \% \text { free PSA level } \leq 15\end{array}$ \\
\hline $\begin{array}{l}\text { Kirby et al, }{ }^{21} \\
1994\end{array}$ & $\begin{array}{l}\text { United } \\
\text { Kingdom }\end{array}$ & Prospective cohort study & 568 & 29 & $55-70$ & $\begin{array}{l}\text { Abnormal DRE findings or PSA } \\
\text { level }>4 \mathrm{ng} / \mathrm{mL}\end{array}$ \\
\hline $\begin{array}{l}\text { Pederson } \\
\text { et } a_{1}, 221990\end{array}$ & Sweden & Prospective cohort study & 1,163 & 34 & $50-69$ & Abnormal DRE findings \\
\hline
\end{tabular}

Table 2. Study Quality Assessment According to QUADAS-2 Tool

\begin{tabular}{|c|c|c|c|c|c|c|c|}
\hline \multirow[b]{2}{*}{ Study, Year } & \multicolumn{4}{|c|}{ Risk of Bias } & \multicolumn{3}{|c|}{ Applicability Concerns } \\
\hline & $\begin{array}{c}\text { Patient } \\
\text { Selection }\end{array}$ & $\begin{array}{c}\text { Index } \\
\text { Test }\end{array}$ & $\begin{array}{l}\text { Reference } \\
\text { Standard }\end{array}$ & $\begin{array}{l}\text { Flow and } \\
\text { Timing }\end{array}$ & $\begin{array}{c}\text { Patient } \\
\text { Selection }\end{array}$ & $\begin{array}{c}\text { Index } \\
\text { Test }\end{array}$ & $\begin{array}{l}\text { Reference } \\
\text { Standard }\end{array}$ \\
\hline Al-Azab et al, ${ }^{16} 2007$ & High & High & Low & High & Unclear & Unclear & Low \\
\hline Brett, $_{1}^{17} 1998$ & Unclear & Low & Low & High & Low & Low & Low \\
\hline Crawford et al, ${ }^{18} 1999$ & Unclear & High & Low & High & Low & Unclear & Low \\
\hline Faria et al, 2012 & Unclear & High & Low & High & Low & Unclear & Low \\
\hline Kirby et al, ${ }^{21} 1994$ & Low & Low & Low & High & Low & Low & Low \\
\hline Pederson et al, ${ }^{22} 1990$ & Low & Low & Low & High & Low & Low & Low \\
\hline
\end{tabular}

onstrate their effectiveness and that the overall benefits of screening should outweigh harms. ${ }^{27}$ As it stands, DRE does not meet these criteria. Surprisingly, a majority of Canadian primary care physicians routinely use DRE. One survey of 955 primary care physicians in Ontario found that $81 \%$ reported using both PSA and DRE to screen for prostate cancer, 9.4\% reported using DRE alone, $7.2 \%$ reported using PSA alone, and $8.3 \%$ did not offer prostate cancer screening at all. ${ }^{28}$ Although the majority of physicians in this sample offered screening, only $38 \%$ believed it provided a survival benefit. On the basis of the lack of evidence supporting its use, we do not recommend routinely using DRE as a screening tool for prostate cancer in primary care, unless it is proven effective in future studies. Additionally, although we did not study possible harms of DRE, its invasiveness and potential to lead to unnecessary biopsy, overdiagnosis, and overtreatment argue against its routine use..$^{2,4-6}$
Our study has several limitations. Many studies do not explicitly report the setting in which, or by whom, the DRE is performed, this uncertainty creates difficulty in ensuring that all relevant literature is captured. Among the 7 studies meeting eligibility criteria, there was substantial variation in both setting and reported diagnostic accuracy of DRE. The latter may be partly explained by the lack of a universal definition for an abnormal DRE. ${ }^{29}$ These limitations, the paucity of published data, and the lack of high-quality randomized controlled trials on this topic make it difficult to interpret the results of our meta-analysis and decrease the reliability of our findings. Finally, for ethical reasons, only patients with a positive DRE or elevated PSA level underwent a biopsy, potentially underestimating the false-negative rate, and thus overestimating the sensitivity and NPV of DRE.

In conclusion, there is a paucity of data evaluating the effectiveness of DRE in the primary care set- 
Table 3. Study Quality of Evidence According to GRADE Guidelines

\begin{tabular}{|c|c|c|c|c|c|c|c|c|}
\hline \multirow[b]{2}{*}{ Outcomes } & \multirow{2}{*}{$\begin{array}{l}\text { No. of } \\
\text { Studies } \\
\text { (No. of } \\
\text { Patients) }\end{array}$} & \multirow[b]{2}{*}{$\begin{array}{l}\text { Study } \\
\text { Design }\end{array}$} & \multicolumn{6}{|c|}{ Domain } \\
\hline & & & $\begin{array}{c}\text { Risk } \\
\text { of Bias }\end{array}$ & Indirectness & Inconsistency & Imprecision & $\begin{array}{c}\text { Publication } \\
\text { Bias }\end{array}$ & $\begin{array}{l}\text { Test of } \\
\text { Accuracy }\end{array}$ \\
\hline \multicolumn{9}{|c|}{ Sensitivity and specificitya } \\
\hline $\begin{array}{l}\text { True positive } \\
\text { and false } \\
\text { negative }\end{array}$ & $6(3,304)$ & $\begin{array}{l}\text { Cross-sectional } \\
\text { (cohort type } \\
\text { accuracy study) }\end{array}$ & Serious ${ }^{b}$ & Not serious & Very serious ${ }^{c}$ & Very serious $^{d}$ & None & Very low \\
\hline $\begin{array}{l}\text { True negative } \\
\text { and false } \\
\text { positive }\end{array}$ & $4(5,877)$ & $\begin{array}{l}\text { Cross-sectional } \\
\text { (cohort type } \\
\text { accuracy study) }\end{array}$ & Serious ${ }^{b}$ & Not serious & Very seriouse & Very serious $^{d}$ & None & Very low \\
\hline \multicolumn{9}{|l|}{ PPV and NPV ${ }^{f}$} \\
\hline $\begin{array}{l}\text { True positive } \\
\text { and false } \\
\text { positive }\end{array}$ & $6(4,581)$ & $\begin{array}{l}\text { Cross-sectional } \\
\text { (cohort type } \\
\text { accuracy study) }\end{array}$ & Serious $^{b}$ & Not serious & Very serious ${ }^{9}$ & Very serious $^{d}$ & None & Very low \\
\hline $\begin{array}{l}\text { True negative } \\
\text { and false } \\
\text { negative }\end{array}$ & $4(4,634)$ & $\begin{array}{l}\text { Cross-sectional } \\
\text { (cohort type } \\
\text { accuracy study) }\end{array}$ & Serious ${ }^{b}$ & Not serious & Very serious ${ }^{h}$ & Very serious $^{\mathrm{d}}$ & None & Very low \\
\hline \multicolumn{9}{|c|}{ GRADE = Grades of Recommendation Assessment, Development, and Evaluation; NPV = negative predictive value; PPV = positive predictive value. } \\
\hline $\begin{array}{l}\text { a Sensitivity }=0.51 \\
{ }^{\mathrm{b}} \text { According to Qua } \\
\text { ' Unexplained hete } \\
{ }^{\mathrm{d}} \text { The confidence in } \\
{ }^{\mathrm{e}} \text { Unexplained hete } \\
{ }^{\mathrm{f}} \mathrm{PPV}=0.41 \text { (95\% } \\
{ }^{9} \text { Unexplained hete } \\
{ }^{\mathrm{h}} \text { Unexplained hete }\end{array}$ & $\begin{array}{l}5 \% \mathrm{Cl}, 0.36-0 . \\
\text { y Assessment o } \\
\text { geneity betwe } \\
\text { rval is a range } \\
\text { geneity betwe } \\
0.31-0.52) ; \mathrm{NI} \\
\text { geneity betwe } \\
\text { geneity betwe }\end{array}$ & 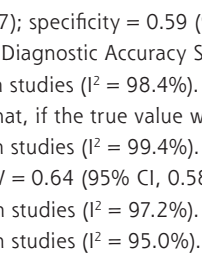 & $\begin{array}{l}\% \text { Cl, } 0.41-0 \text {. } \\
\text { dies } 2 \text { tool, al } \\
\text { a to lie within } \\
70)\end{array}$ & $\begin{array}{l}\text { 6). } \\
\text { studies included } \\
\text { it, would result in }\end{array}$ & $\begin{array}{l}\text { this meta-analysis } \\
\text { different clinical dec }\end{array}$ & ions depending o & $\begin{array}{l}\text { significant risk } \\
\text { where it fell. }\end{array}$ & bias concerns \\
\hline
\end{tabular}

\section{Table 4. Summary Findings and Meta-Analysis of Diagnostic Accuracy of DRE for Prostate Cancer Screening in Primary Care Settings}

\begin{tabular}{|c|c|c|c|c|}
\hline Study, Year & Sensitivity & Specificity & PPV & NPV \\
\hline Al-Azab et al, ${ }^{16} 2007$ & 0.50 & 0.61 & 0.49 & 0.62 \\
\hline Brett, $^{17} 1998$ & 0.67 & N/A & N/A & $N / A$ \\
\hline Crawford et al, ${ }^{18} 1999$ & 0.65 & 0.37 & 0.29 & 0.72 \\
\hline Elliott et al, ${ }^{19} 2008$ & 0.65 & 0.65 & 0.52 & 0.64 \\
\hline Faria et al, ${ }^{20} 2012$ & 0.24 & 0.72 & 0.36 & 0.59 \\
\hline Kirby et al, ${ }^{21} 1994$ & 0.73 & $\mathrm{~N} / \mathrm{A}$ & N/A & $N / A$ \\
\hline Pederson et al, 221990 & N/A & $N / A$ & 0.26 & N/A \\
\hline \multicolumn{5}{|l|}{ Pooled analysis ${ }^{a}$} \\
\hline Estimate $(95 \% \mathrm{Cl})$ & $\begin{array}{c}0.51 \\
(0.36-0.67)\end{array}$ & $\begin{array}{c}0.59 \\
(0.41-0.76)\end{array}$ & $\begin{array}{c}0.41 \\
(0.31-0.52)\end{array}$ & $\begin{array}{c}0.64 \\
(0.58-0.70)\end{array}$ \\
\hline Heterogeneity: $1^{2}, \%$ & 98.4 & 99.4 & 97.2 & 95.0 \\
\hline
\end{tabular}

DRE = digital rectal examination; NPV = negative predictive value; $N / A=$ not available; $P P V=$ positive predictive value.

a Pooled analysis of data from 6 studies of 3,304 patients total for sensitivity; 4 studies of 5,877 patients total for specificity; 6 studies of 4,581 patients total for positive predictive value; and 4 studies of 4,634 patients total for negative predictive value.
Key words: digital rectal examination; prostatic neoplasms; malignancy; diagnosis; primary health care

Submitted April 19, 2017; submitted, revised, September 21, 2017; accepted October 4, 2017.

Systematic review registration: PROSPERO CRD42016042585. July 8, 2016.

Authors' contributions: J.P. and L.N. conceived the research question. J.P., L.N., and B.D. designed the review protocol. L.N. and L.B. designed the search strategy, which was completed by L.B. The systematic screening of studies for inclusion independently and in duplicate was completed by J.P., L.N., H.R., B.D., D.W., O.K., and M.B. L.N. and H.R. performed data extraction and quality assessment of included studies independently and in duplicate. Z.S. performed analyses. All authors contributed equally to the writing and revision of the manuscript. All authors approved the final version of the manuscript.

Acknowledgments: We would like to thank Dr Kari Tikkinen for his contributions to study design. ting. Given the findings of our analysis and appraisal of available studies, we do not recommend routine screening for prostate cancer using DRE in primary care, so as to minimize unnecessary diagnostic testing, overdiagnosis, and overtreatment.

To read more or post commentaries in response to this article, see it online at http://www.AnnFamMed.org/content/16/2/149.
Supplementary materials: Available at http://www.AnnFamMed. org/content/16/2/149/suppl/DC1/.

\section{References}

1. American Cancer Society. Global Cancer Facts \& Figures. 3rd ed. Atlanta, GA: American Cancer Society; 2015. 
2. Tawfik A. Prostate-Specific Antigen (PSA)-Based Population Screening for Prostate Cancer: An Economic Analysis. Ont Health Technol Assess Ser. 2015;15(11):1-37.

3. Wallner L, Frencher S, Hsu JW, et al. Prostate cancer screening trends in a large, integrated health care system. Perm J. 2012;16(3): 4-9.

4. Ilic D, Neuberger MM, Djulbegovic M, Dahm P. Screening for prostate cancer. Cochrane Database Syst Rev. 2013;(1):CD004720.

5. Morgan E, Drummond FJ, Coyle C, Sharp L, Gavin AT. Physical after-effects in men undergoing prostate biopsy in routine clinical practice: Results from the PiCTure study. Urol Oncol. 2017;35(10): 604.e11-604.e16.

6. Cui T, Kovell RC, Terlecki RP. Is it time to abandon the digital rectal examination? Lessons from the PLCO Cancer Screening Trial and peer-reviewed literature. Curr Med Res Opin. 2016;Jul 4:1-7.

7. Izawa JI, Klotz L, Siemens DR, et al. Prostate cancer screening: Canadian guidelines 2011. Can Urol Assoc J. 2011;5(4):235-240.

8. Bell N, Connor Gorber S, Shane A, et al. Recommendations on screening for prostate cancer with the prostate-specific antigen test. CMAJ. 2014;186(16):1225-1234.

9. Mistry K, Cable G. Meta-analysis of prostate-specific antigen and digital rectal examination as screening tests for prostate carcinoma. J Am Board Fam Pract. 2003;16(2):95-101.

10. Hoogendam A, Buntinx F, de Vet HC. The diagnostic value of digital rectal examination in primary care screening for prostate cancer: a meta-analysis. Fam Pract. 1999;16(6):621-626.

11. Covidence systematic review software, Veritas Health Innovation, Melbourne, Australia. Available at http://www.covidence.org. Accessed Jul 27, 2016.

12. Whiting PF, Rutjes AW, Westwood ME, et al.; QUADAS-2 Group. QUADAS-2: a revised tool for the quality assessment of diagnostic accuracy studies. Ann Intern Med. 2011;155(8):529-536.

13. Balshem $H$, Helfand $M$, Schünemann $H J$, et al. GRADE guidelines: 3. Rating the quality of evidence. J Clin Epidemiol. 2011;64(4): 401-406.

14. MedCalc Statistical Software version 16.8.4, MedCalc Software BVBA, Ostend, Belgium. https://http://www.medcalc.org. Published 2017. Accessed Jan 23, 2017.

15. R Core Team. R: A language and environment for statistical computing. R Foundation for Statistical Computing, Vienna, Austria. http://www.R-project.org/. Published 2013.

16. Al-Azab R, Toi A, Lockwood G, Kulkarni GS, Fleshner N. Prostate volume is strongest predictor of cancer diagnosis at transrectal ultrasound-guided prostate biopsy with prostate-specific antigen values between 2.0 and $9.0 \mathrm{ng} / \mathrm{mL}$. Urology. 2007;69(1):103-107.
17. Brett TD. An analysis of digital rectal examination and serumprostate-specific antigen in the early detection of prostate cancer in general practice. Fam Pract. 1998;15(6):529-533.

18. Crawford ED, Leewansangtong S, Goktas S, Holthaus K, Baier M. Efficiency of prostate-specific antigen and digital rectal examination in screening, using $4.0 \mathrm{ng} / \mathrm{ml}$ and age-specific reference range as a cutoff for abnormal values. Prostate. 1999;38(4):296-302.

19. Elliott CS, Shinghal R, Presti JC Jr. Racial variations in the performance of prostate specific antigen and prostate specific antigen density in the era of extended prostate biopsy schemes. J Urol. 2008;180(4):1318-1323; discussion 1323-1314.

20. Faria EF, Carvalhal GF, dos Reis RB, et al. Use of low free to total PSA ratio in prostate cancer screening: detection rates, clinical and pathological findings in Brazilian men with serum PSA levels $<4.0$ ng/mL. BJU Int. 2012;110(11 Pt B):E653-E657.

21. Kirby RS, Kirby MG, Feneley MR, McNicholas T, McLean A, Webb JA. Screening for carcinoma of the prostate: a GP based study. Br J Urol. 1994;74(1):64-71.

22. Pedersen KV, Carlsson P, Varenhorst E, Löfman O, Berglund K. Screening for carcinoma of the prostate by digital rectal examination in a randomly selected population. BMJ. 1990;300(6731): 1041-1044.

23. Curran V, Solberg S, Mathews M, et al. Prostate cancer screening attitudes and continuing education needs of primary care physicians. J Cancer Educ. 2005;20(3):162-166.

24. Hoag NA, Davidson RA. PJ P. Prostate cancer screening practices and attitudes among primary care physicians in Victoria, British Columbia. BCMJ. 2008;50(8):456-460.

25. Nensi A, Chande N. A survey of digital rectal examination training in Canadian medical schools. Can J Gastroenterol. 2012;26(7): 441-444.

26. Smith DS, Catalona WJ. Interexaminer variability of digital rectal examination in detecting prostate cancer. Urology. 1995;45(1): 70-74.

27. Andermann A, Blancquaert I, Beauchamp S, Déry V. Revisiting Wilson and Jungner in the genomic age: a review of screening criteria over the past 40 years. Bull World Health Organ. 2008;86(4):317-319.

28. Allard CB, Dason S, Lusis J, Kapoor A. Prostate cancer screening: Attitudes and practices of family physicians in Ontario. Can Urol Assoc J. 2012;6(3):188-193.

29. Yilmaz O, Kurul O, Ates F, Soydan H, Aktas Z. Does an asymmetric lobe in digital rectal examination include any risk for prostate cancer? Results of 1495 biopsies. Int Braz J Urol. 2016;42(4):704-709. 